\title{
A COMPARATIVE ANALYSIS OF THE LEVEL OF URBAN RESILIENCE IN THE CITY COMPREHENSIVE PLAN
}

\author{
KIM MIN-SEOK, YOU-MI JEON \& JEA-SUN LEE \\ Department of Urban Planning, Yonsei University, South Korea
}

\begin{abstract}
In recent years, due to rapid changes in society, and climate change, cities have experienced difficulties in predicting various types of upcoming hazards and stresses. Uncertainties about the nature and extent of risks are increased especially when it comes to cities where interactions exist among various elements including human, society, economy, and culture. Considering limited prediction on inherent crises and difficulties in reaction plans, resilience strategy should be implemented prior to prevention strategy. The purpose of this study is to compare urban resilience levels of comprehensive plans for metropolitan areas with a population of over 1 million. Resilience measurements of capacity of resistance, adaptation, and recovery from external shocks and stresses will be applied to evaluate the level of urban resilience of cities in Korea. For the method of the study, it defined concepts of urban resilience through literature review, and derived indexes for urban resilience using preceding researches and case studies. Then, it developed detailed assessment indexes for evaluation of urban resilience level, and, finally, it evaluated and compared urban resilience level of comprehensive plans, using derived assessment indexes. As a result of the study, it suggested 56 assessment indexes and checklists in 8 sectors including land use plan, urban and residential environment, infrastructure, and more. The result of this study can be used as a base data for the future comprehensive plans when developing resilient cities.

Keywords: urban resilience, indicator, city comprehensive plan, checklist analysis.
\end{abstract}

\section{INTRODUCTION}

It is impossible to predict various risks such as disasters and economic crises in cities due to globalization and climate change, and the complexity increased due to the interactions of various factors such as humanities, society, and economy. Thus, the unpredictability and uncertainty of risk are maximized. For this reason, it is argued that the urban resilience force should be increased beyond the prevention of individual incidents or local accidents that occur in the city, as the awareness of the limitation on the prevention of urban planning is increasing.

Urban resilience is necessary because city problems cannot be overcome by simply eliminating or preventing a single risk factor from a preventive point of view, but rather mitigating damage, improving vulnerability and adaptability to change. Therefore, it is necessary to have a city-planning strategy to comprehensively consider all factors. Resilience strategy can also be more effective than prevention strategy if the city's potential risk or crisis prediction is limited, and it is difficult to find a countermeasure [1].

The purpose of this study is to analyse the urban resilience level of urban comprehensive plan in order to build resilient cities in a metropolitan. Applying the concept of urban resilience that can cope with external shocks and stresses to domestic cities, diagnose and analyse the resilience of each city, and contribute to sustainable urban development by presenting resilience factors to be reflected in urban planning, it is possible to search for directions.

The purpose of this study is as follows: first, analysing the concrete contents of the city's comprehensive plan, which is a top-level plan established at the city level, and examine the relationship between city comprehensive plan and urban resilience by examining theories, researches, and applications related to urban resilience. Secondly, to establish a resilient 
urban plan that reflects local characteristics, we will build an index of urban resilience indicators for each sector and compare the resilience levels of existing city comprehensive plans. Through this, this study will propose a direction and policy and institutional improvement plan which should be aimed at creating a resilient city when establishing the city comprehensive plan in the future.

The spatial and temporal scope of this study covers 4 out of the 5 cities except Seoul, where the 2030 city comprehensive plan was established among more than 1 million large cities in Korea. The contextual scope is limited to assessing the level of resilience through a context analysis and the divisional elements of the city comprehensive plan are reviewed with a focus on urban resilience [2].

The research method is as follows: First, the concept of city comprehensive plan and city resilience is defined through literature review, and diagnosis index related to resilience is derived through precedent research and case study. Second is based on the derived diagnosis index, it analyses the degree of the city's recovery ability in the current city comprehensive plan establishment guidelines and builds detailed evaluation index by each component. Third is a checklist, it was prepared based on the detailed evaluation index to evaluate the urban resilience level of the city comprehensive plan.

\section{LITERATURE REVIEW}

\subsection{City comprehensive plan}

The city comprehensive plan is a national plan established in accordance with Article 19 (3) of the National Land Planning and Utilization Act and Article 16 is the Enforcement Decree of the same Act, which has the status of a top-level plan established at the city level. The status and significance of the city comprehensive plan are shown in Table 1 and Fig. 1, respectively. It suggests a policy direction that can improve the quality of life of residents by efficiently utilizing the limited resources of the country efficiently and rationally, and to develop the liveable and sustainable. At the same time, it has the character of a comprehensive plan that suggests a structural framework to develop the city spatially over the long term.

Table 1: The significance of city comprehensive plan. (Source: ministry of land and transport affairs, 2015.)

\begin{tabular}{|c|c|c|}
\hline \multicolumn{2}{|c|}{ Category } & Range \\
\hline \multicolumn{2}{|c|}{ Sustainable } & $\begin{array}{l}\text { Ensure sustainability of national land management for utilization and } \\
\text { development and conservation of the country. }\end{array}$ \\
\hline \multirow[t]{3}{*}{$\begin{array}{l}\text { An } \\
\text { integrated } \\
\text { approach }\end{array}$} & Environmental & $\begin{array}{l}\text { Rapid growth of cities and prevention of spread of global climate } \\
\text { change. } \\
\text { Active response to global warming and reduction of carbon emissions. }\end{array}$ \\
\hline & Economical & $\begin{array}{l}\text { Job Creation in the Region. } \\
\text { Urban regeneration and activation of local economy. } \\
\text { Seek economic efficiency of resource utilization. } \\
\text { Achieve cost-effective urban development and achieve low carbon green } \\
\text { growth. }\end{array}$ \\
\hline & Social & $\begin{array}{l}\text { Considering social equity (collecting opinions of various interests of } \\
\text { community, reflecting). } \\
\text { Contributing to the promotion of social capital (social conflict } \\
\text { minimization, integration promotion). } \\
\text { Establishing a plan that takes into account social disadvantages (low- } \\
\text { income, elderly, disabled, etc.). } \\
\text { Enhancing community cultural diversity. }\end{array}$ \\
\hline
\end{tabular}




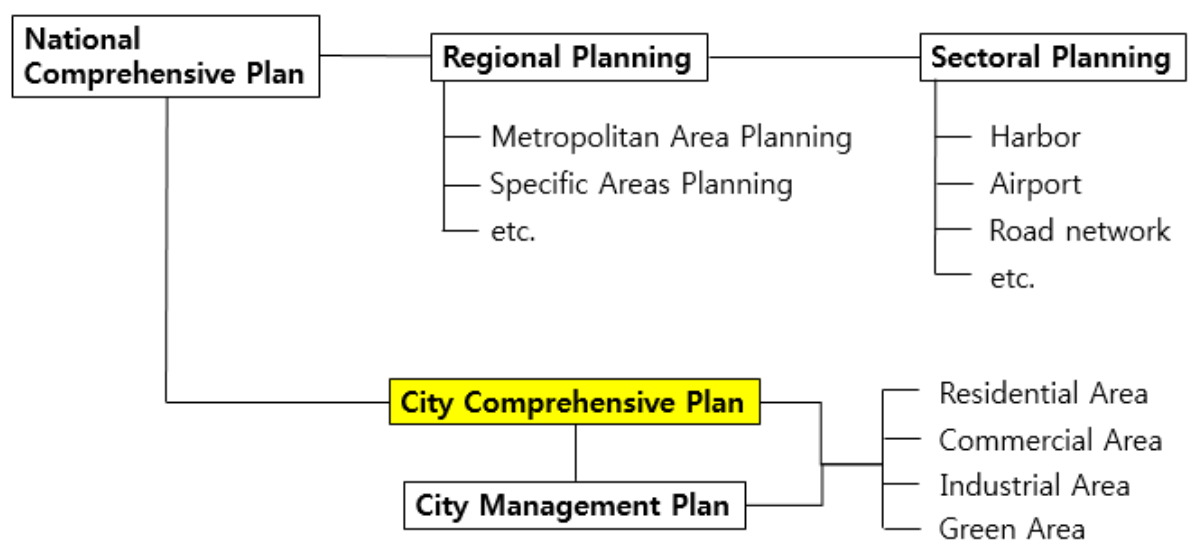

Figure 1: The status of city comprehensive plan. (Source: Ministry of Land and Transport Affairs, 2015.)

Most studies dealing with linkages between urban comprehensive planning and resilience are addressed in the areas of carbon reduction and disaster prevention. "Evaluation of Urban Comprehensive Plan with Disaster Cities Indicators” by Lee Seung-hee (2013), “Assessment and Analysis of Disaster Prevention and Safety Plan Planning by City Comprehensive Plan" by Park, Joon Sung (2014) and "A Comparative Analysis of Carbon Abatement Strategies in the City Comprehensive Plan” by Henan Suo (2014).

\subsection{Urban resilience}

Resilience comes from the Latin word "Resilio", which means “To jump back," and has been applied and spread in various fields such as ecology, engineering, economics, and psychology [3]. Resilience is largely classified into three concepts.

Resilience can be applied at the urban and community level. As urbanization accelerates due to industrialization and technological development, the proportion of the population living in the city has increased, and the quality of life has increased, so that infrastructure, public service and welfare demand are also increasing. On the other hand, as cities become increasingly overcrowded and complicated, they are more likely to be exposed to external risks or shocks as well as more difficult to forecast and the extent of damage is also

Table 2: Three concepts of resilience [4].

\begin{tabular}{|c|c|c|c|}
\hline Concepts & Characteristic & Focus & Context \\
\hline Engineering & Recovery period & Recovery & Stable \\
\hline Ecological & $\begin{array}{l}\text { Efficiency } \\
\text { Buffer capacity } \\
\text { Shock mitigation } \\
\text { Maintain function }\end{array}$ & $\begin{array}{l}\text { Robust } \\
\text { Sustainability } \\
\text { Durability }\end{array}$ & $\begin{array}{l}\text { Balance state } \\
\text { Multiple balance }\end{array}$ \\
\hline $\begin{array}{l}\text { Social- } \\
\text { ecological }\end{array}$ & $\begin{array}{l}\text { Maintaining and developing } \\
\text { interactions of disability and re- } \\
\text { organization }\end{array}$ & $\begin{array}{l}\text { Adaptive Capacity } \\
\text { Multi-variate } \\
\text { Learning and } \\
\text { Innovation }\end{array}$ & $\begin{array}{l}\text { Integrated and } \\
\text { active interaction }\end{array}$ \\
\hline
\end{tabular}


Table 3: Definition of urban resilience.

\begin{tabular}{ll}
\hline \multicolumn{1}{c}{ Author } & \multicolumn{1}{c}{ Definition } \\
\hline Godschalk [5] & $\begin{array}{l}\text { Ability to resist shock without immediate } \\
\text { chaos or permanent deformation or breakage. }\end{array}$ \\
\hline Sophie and & $\begin{array}{l}\text { Ability to resist or absorb dangerous effects } \\
\text { through resistance and adaptation that can } \\
\text { Cassidy [6] } \\
\text { maintain and restore or recover basic and } \\
\text { essential functions and structures in a crisis } \\
\text { situation. }\end{array}$ \\
\hline
\end{tabular}

increasing. Therefore, it is important to discuss resilience from the perspective of the city and the community.

Resilience in Korea research is expressed in various words such as disinfection ability, and resilience in the area of disaster prevention and the regional policy development. First, the research on the resilience of disaster prevention is based on the "Development of Indicators and Checklist for Urban Disaster Risk Assessment" [2], "Resilience Analysis of Climate Disasters in Local Governments" and Disaster Resilience Measurement (UNDP) (2014), which provides methods for measuring resilience recovery, And the "City Resilience Index" of Arup [1], which summarizes resilience indicators through case studies.

In this study, urban resilience is defined as capacity to improve quality of life and function in urban areas. In order to create a resilient city, it was defined that the qualities of reflective, resourceful, robust, redundant, flexible, inclusive, and integrated were needed.

\section{RESEARCH PLAN}

\subsection{Index set up}

Among the literature review and previous research, City Resilience Framework [1], was presented in 100 Resilient cities, which are building urban resilience networks centred on various examples of recent global cities, (reflective, resourceful, robust, redundant, flexible, inclusive, integrated). It was reconstructed to suit the situation in Korea.

In order to derive the index for the detailed evaluation, the criteria of the evaluation items and the keywords of the urban resilience index presented in the literature review were used. It reviews and analyses the contents of each divisional plan of the Urban Comprehensive Plan Establishment Related to Urban Resilience, and presents criteria for a selection of detailed indicators (land-use, infrastructure, urban and residential environment, environmental, conservation and management, green spaces, disaster prevention, safety and crime prevention, development and promotion of economy, industry, society, culture).

However, for the convenience of evaluation, "disaster prevention and safety and crime prevention" among the seven sectoral plans were limited to the disaster prevention sector, and "development and promotion of the economy, industry, society and culture" was limited to the economy and industry. In the case of "infrastructure" and "environmental preservation and management" it was subdivided into transportation facilities, supply processing facilities (water and sewage, energy, waste), environment preservation and management (air quality, water quality and other natural resources). As a result, we have established 56 detailed indicators based on 8 sectors. 
Table 4: Selection criteria for evaluation index.

\begin{tabular}{ll}
\hline Component & \multicolumn{1}{c}{ Criteria } \\
\hline Reflective & $\begin{array}{l}\text { Analyse the situation and set goals in consideration of the experience } \\
\text { from the risk and the local characteristics. }\end{array}$ \\
\hline Resourceful & Set up index for resource management. \\
\hline Robust & Establish a proactive plan \\
\hline Redundant & Alternative facilities to accommodate the crisis, diversity of systems \\
\hline Flexible & Step by step planning, monitoring \\
\hline Inclusive & Accepting various interests and communication \\
\hline Integrated & Relation between upper-level and related plans and sector-specific plans \\
\hline
\end{tabular}

Table 5: Category and range of urban resilience index in city comprehensive plan.

\begin{tabular}{|c|c|c|}
\hline & Category & Range \\
\hline \multirow[t]{8}{*}{ Reflective } & land-use & $\begin{array}{l}\text { Analysis of inefficient land use area and urban } \\
\text { function distortion area }\end{array}$ \\
\hline & $\begin{array}{l}\text { urban and residential } \\
\text { environment }\end{array}$ & $\begin{array}{l}\text { Declining areas in the city (declining trend of } \\
\text { business, depreciation of buildings etc.) }\end{array}$ \\
\hline & transportation facilities & Regional allocation by transportation \\
\hline & $\begin{array}{l}\text { supply processing } \\
\text { facilities }\end{array}$ & $\begin{array}{l}\text { Supply processing facilities (water and } \\
\text { wastewater, waste, energy) }\end{array}$ \\
\hline & $\begin{array}{l}\text { environment } \\
\text { preservation and } \\
\text { management }\end{array}$ & Air quality, water quality, other natural resources \\
\hline & green spaces & Park green space related \\
\hline & disaster prevention & $\begin{array}{l}\text { Analysis of disaster risk factors/disaster } \\
\text { prevention systems by disaster type }\end{array}$ \\
\hline & economy and industry & $\begin{array}{l}\text { Establishment of planning goals through } \\
\text { analyzing current economic situation }\end{array}$ \\
\hline \multirow[t]{8}{*}{ Resourceful } & land-use & $\begin{array}{l}\text { Setting of available land supply considering local } \\
\text { characteristics }\end{array}$ \\
\hline & $\begin{array}{l}\text { urban and residential } \\
\text { environment }\end{array}$ & Establish planned supply plan for housing \\
\hline & transportation facilities & Establishment of traffic related indicators \\
\hline & $\begin{array}{l}\text { supply processing } \\
\text { facilities }\end{array}$ & $\begin{array}{l}\text { Providing indicators related to supply processing } \\
\text { facilities }\end{array}$ \\
\hline & $\begin{array}{l}\text { environment } \\
\text { preservation and } \\
\text { management }\end{array}$ & $\begin{array}{l}\text { Establishing indicators } \\
\text { atmosphere/water environment }\end{array}$ \\
\hline & green spaces & $\begin{array}{l}\text { Establishment of indicators related to parks and } \\
\text { green spaces }\end{array}$ \\
\hline & disaster prevention & $\begin{array}{l}\text { Establishment of indicators related to disaster } \\
\text { prevention facilities }\end{array}$ \\
\hline & economy and industry & $\begin{array}{l}\text { Establishment of economic scale, industrial } \\
\text { structure, income, consumption structure, and } \\
\text { financial indicators }\end{array}$ \\
\hline
\end{tabular}


Table 5: Continued.

\begin{tabular}{|c|c|c|}
\hline & Category & Range \\
\hline \multirow[t]{7}{*}{ Robust } & land-use & Efficient use of land resources (standard) \\
\hline & $\begin{array}{l}\text { urban and residential } \\
\text { environment }\end{array}$ & $\begin{array}{l}\text { Balanced regional development strategy } \\
\text { (urban/rural, new and old) }\end{array}$ \\
\hline & transportation facilities & $\begin{array}{l}\text { Utilization of city"s internal and external traffic } \\
\text { networks and improvement of accessibility }\end{array}$ \\
\hline & $\begin{array}{l}\text { supply processing } \\
\text { facilities }\end{array}$ & Stable supply plan of supply processing facility \\
\hline & $\begin{array}{l}\text { environment preservation } \\
\text { and management }\end{array}$ & $\begin{array}{l}\text { Establish management and reduction plan for } \\
\text { environmental pollution (atmospheric environment, } \\
\text { water quality environment) by media }\end{array}$ \\
\hline & green spaces & Comprehensive green space system plan and plan \\
\hline & disaster prevention & $\begin{array}{l}\text { Disaster prevention plan and disaster prevention } \\
\text { plan prepared for damage }\end{array}$ \\
\hline \multirow[t]{8}{*}{ Redundant } & economy and industry & $\begin{array}{l}\text { Establishment of industry-specific (1st, 2nd, 3rd) } \\
\text { development plan }\end{array}$ \\
\hline & land-use & Securing adequate amount of conservation land \\
\hline & $\begin{array}{l}\text { urban and residential } \\
\text { environment }\end{array}$ & $\begin{array}{l}\text { Planning of various types of residential and } \\
\text { residential complexes considering regional } \\
\text { characteristics and landscape }\end{array}$ \\
\hline & transportation facilities & $\begin{array}{l}\text { Plan for alternative transportation facilities and } \\
\text { spare capacity (transit transportation facility } \\
\text { planning) }\end{array}$ \\
\hline & $\begin{array}{l}\text { supply processing } \\
\text { facilities }\end{array}$ & $\begin{array}{l}\text { Planning for alternative supply processing facilities } \\
\text { and spare capacity }\end{array}$ \\
\hline & $\begin{array}{l}\text { environment preservation } \\
\text { and management }\end{array}$ & Environment-friendly development promotion plan \\
\hline & green spaces & $\begin{array}{l}\text { Disaster prevention function and pollutant reduction } \\
\text { plan in waterside space and park green space } \\
\text { facility }\end{array}$ \\
\hline & disaster prevention & $\begin{array}{l}\text { Plan for spare capacity for alternative disaster } \\
\text { prevention facilities and disasters }\end{array}$ \\
\hline \multirow[t]{8}{*}{ Flexible } & economy and industry & $\begin{array}{l}\text { Specialized industrial plan for strengthening } \\
\text { regional competitiveness }\end{array}$ \\
\hline & land-use & $\begin{array}{l}\text { Step-by-step development plan of developmental } \\
\text { land (monitoring) }\end{array}$ \\
\hline & $\begin{array}{l}\text { urban and residential } \\
\text { environment }\end{array}$ & Urban Renewal Plan \\
\hline & transportation facilities & Green / New traffic planning \\
\hline & $\begin{array}{l}\text { supply processing } \\
\text { facilities }\end{array}$ & $\begin{array}{l}\text { Planning and implementation of resource } \\
\text { circulation system (monitoring) }\end{array}$ \\
\hline & $\begin{array}{l}\text { environment preservation } \\
\text { and management }\end{array}$ & Low carbon green growth plan \\
\hline & green spaces & $\begin{array}{l}\text { Green space planning to respond flexibly to changes } \\
\text { in conditions }\end{array}$ \\
\hline & disaster prevention & $\begin{array}{l}\text { Plan for the construction and operation of } \\
\text { comprehensive disaster prevention system } \\
\text { (monitoring) }\end{array}$ \\
\hline
\end{tabular}


Table 5: Continued.

\begin{tabular}{|c|c|c|}
\hline & Category & Range \\
\hline \multirow[t]{9}{*}{ Inclusive } & $\begin{array}{l}\text { economy and } \\
\text { industry }\end{array}$ & Old age industrial park recycling plan \\
\hline & land-use & $\begin{array}{l}\text { Establishment of land use plan considering various } \\
\text { stakeholders }\end{array}$ \\
\hline & $\begin{array}{l}\text { urban and residential } \\
\text { environment }\end{array}$ & $\begin{array}{l}\text { Establish measures to improve the living standards of } \\
\text { vulnerable groups (low-income families, multicultural } \\
\text { families, etc.) }\end{array}$ \\
\hline & $\begin{array}{l}\text { transportation } \\
\text { facilities }\end{array}$ & $\begin{array}{l}\text { Establishment of transportation plan considering social } \\
\text { vulnerable classes }\end{array}$ \\
\hline & $\begin{array}{l}\text { Supply processing } \\
\text { facilities }\end{array}$ & Supply planning of supply facilities in backward region \\
\hline & $\begin{array}{l}\text { environment } \\
\text { preservation and } \\
\text { management }\end{array}$ & $\begin{array}{l}\text { Environmental preservation and management plan } \\
\text { considering various stakeholders }\end{array}$ \\
\hline & green spaces & $\begin{array}{l}\text { Park green space planning considering regional, } \\
\text { intergenerational, and inter-tier equality }\end{array}$ \\
\hline & disaster prevention & $\begin{array}{l}\text { Preparing measures to reduce disaster damage to poor } \\
\text { people (poor) }\end{array}$ \\
\hline & economy and industry & Planning for the vulnerable \\
\hline Integ & & $\begin{array}{l}\text { Top and related plans (related planning, divisional } \\
\text { planning) and linkages }\end{array}$ \\
\hline
\end{tabular}

This study evaluated the urban resilience of the sectoral plans and assessed the urban resilience level of the domestic cities, and the evaluation method of Brody [11], which was used for the evaluation. The evaluation criteria are evaluated as $0-2$ according to the degree of the concrete establishment of the plan. If the contents of the plan are not reflected yet, or if the contents of the plan are reflected in the plan in general, or if the plan is reflected in the plan comprehensively, 2 points will be awarded if the plan is reflected specifically in 1 point, the sum of the index values composed of the two-point scale thus calculated is converted into 100 points by the following eqn (1).

$$
\mathrm{UR}_{j}=\frac{100}{2 m_{j}} \sum_{i=1}^{m_{j}} I_{i}
$$

- $\mathrm{UR}_{j}$ : Indicator score of urban resilience type (j)

- $m_{j} \quad$ : Number of detailed indices of indices of urban resilience type (j)

- $I_{i} \quad$ : I-th detail indicator score

The scores of each indicator were then averaged by city resilience type to assess city resilience level by city. Eqn (2) is evaluation.

$$
\mathrm{L}=\frac{1}{n} \sum_{i=1}^{n} U R_{j}
$$

- $\quad L \quad$ : Level of plan by urban resilience type

- $n$ : Number of indicators by type of urban resilience 


\section{RESULT OF ANALYSIS}

\subsection{Urban resilience level assessment}

The resilience level of the city was 66.7 in Incheon city, 49.4 in Suwon city, 47.3 in Ulsan city, and 45.5 in Daejeon city, and the average was 52.5. Considering the difference in planning and timing of cities, the score is gradually increasing, which suggests that urban resilience level is improving and developing in urban comprehensive plans [7]-[10].

\subsection{Urban resilience level by indicator}

The results of the evaluation of urban resilience level for each component are shown in the table above. It can be seen that inclusive and integration are relatively.

The resilience level of the sectoral plans are as follows. The urban resilience level of each sectoral plan shows an almost equal evaluation.

Table 6: Urban resilience level table (components).

\begin{tabular}{|c|c|c|c|c|c|}
\hline Component & $\begin{array}{c}\text { Daejeon } \\
(2013)\end{array}$ & $\begin{array}{c}\text { Suwon } \\
(2014)\end{array}$ & $\begin{array}{c}\text { Incheon } \\
(2015)\end{array}$ & $\begin{array}{c}\text { Ulsan } \\
(2016)\end{array}$ & Average \\
\hline Reflective & 66.7 & 70.8 & 72.9 & 66.7 & 69.275 \\
\hline Resourceful & 56.3 & 54.2 & 79.2 & 47.9 & 59.4 \\
\hline Robust & 52.1 & 54.2 & 72.9 & 58.3 & 59.375 \\
\hline Redundant & 37.5 & 39.6 & 66.7 & 50.0 & 48.45 \\
\hline Flexible & 52.1 & 56.3 & 72.9 & 45.8 & 56.775 \\
\hline Inclusive & 29.2 & 31.3 & 47.9 & 35.4 & 35.95 \\
\hline Integrated & 25.0 & 39.6 & 54.2 & 27.1 & 36.475 \\
\hline
\end{tabular}

Table 7: Urban resilience level table (sectoral plans).

\begin{tabular}{|l|c|c|c|c|c|}
\hline \multicolumn{1}{|c|}{ Sectoral Plan } & $\begin{array}{c}\text { Daejeon } \\
(2013)\end{array}$ & $\begin{array}{c}\text { Suwon } \\
(2014)\end{array}$ & $\begin{array}{c}\text { Incheon } \\
(2015)\end{array}$ & $\begin{array}{c}\text { Ulsan } \\
(2016)\end{array}$ & Average \\
\hline Land-use & 57.1 & 57.1 & 66.7 & 45.2 & 56.525 \\
\hline $\begin{array}{l}\text { Urban and } \\
\text { residential } \\
\text { environment }\end{array}$ & 42.9 & 57.1 & 69.0 & 42.9 & 52.975 \\
\hline $\begin{array}{l}\text { Transportation } \\
\text { facilities }\end{array}$ & 59.5 & 66.7 & 71.4 & 61.9 & 64.875 \\
\hline $\begin{array}{l}\text { Supply processing } \\
\text { facilities }\end{array}$ & 33.3 & 38.1 & 64.3 & 47.6 & 45.825 \\
\hline $\begin{array}{l}\text { Environment } \\
\text { preservation and } \\
\text { management }\end{array}$ & 42.9 & 45.2 & 64.3 & 52.4 & 51.2 \\
\hline Green spaces & 40.5 & 57.1 & 61.9 & 50.0 & 52.375 \\
\hline Disaster prevention & 47.6 & 38.1 & 54.8 & 33.3 & 43.45 \\
\hline $\begin{array}{l}\text { Economy and } \\
\text { industry }\end{array}$ & 40.5 & 35.7 & 81.0 & 45.2 & 50.6 \\
\hline
\end{tabular}




\section{CONCLUSION}

The purpose of this study is to analyse the current state of resilience of urban resilience in the current city and county comprehensive planning guidelines through national, internal and external resilience indicators. Based on this, it was applied to the city comprehensive plan in 2030 and established in the metropolitan areas (Daejeon city, Suwon city, Incheon city, Ulsan city) with more than 1 million population in Korea, and the urban resilience level of each city was evaluated.

As a result, the city with the lowest resilience of the city is 45.5, Daejeon metropolitan city which was planned in 2013, and the city with the highest resilience of cities is Incheon Metropolitan City, planned in 2015, with average level of 52.2 points.

In this study, the urban resilience level according to the seven qualities of reflectivity, resource mobilization, durability, substitution, flexibility, inclusion and integration defined as the constituent elements of the resilient city showed the highest reflectivity of 69.3 points, and inclusion and integration were relatively low at 35.9 points and 36.5 points, respectively.

In terms of the level of resilience of cities according to each division, the traffic facilities among the infrastructures were 64.9 points, reflecting the most resilience of cities, and the plans for the disaster prevention and supply treatment facilities were less reflective of urban resilience than other plans do.

The results of this study are as follows:

First, the urban comprehensive plan of the city in 2030 shows that the contents of the urban resilience are gradually reflected and embodied over time, though there is a difference in the degree of concrete content due to the conditions and characteristics of each region.

Secondly, the planning of the divisional plan of most cities is based on the analysis of the current plan, the establishment of the comprehensive direction, and the establishment of the relevant indicators such as the planning of the future (reflectivity, resource mobilization) On the other hand, it is analysed that the link between the plan and the plan considering various stakeholders (especially the socially weak) is rather low. Therefore, it will be necessary to revise the city and county comprehensive planning guidelines so that a plan reflecting the inclusion and integration, a component of urban resilience, can be established in order to establish a resilient city plan.

Based on the checklist presented in this study, we suggest the possibility of reflecting the plan to improve the city resilience in the city comprehensive plan of 2030, which will be established in future, this can be suggested as a basis for establishing measures to promote urban resilience by sector in establishing future urban comprehensive planning policies.

Also. It should be considered to create a resilient city when establishing plans related to cities of various sizes and characteristics, such as urban management plans and district unit plans, as well as urban comprehensive plans by introducing national and internal resilience indicators through literature review and prior research This is because it is easy to analyse the urban recovery force index.

As the limitation of this study, the scope of the study is applied to the entire plan of the sector, and related index is derived to evaluate the level of resilience of the city. There is a need to subdivide the indicators and checklists of the Urban Resilience Test.

In assessing the level of urban resilience, it is necessary to analyse whether the implementation of each plan is enriched in the implementation process of the plan, not to determine whether it is reflected in the plan. Further research is required to analyse the results.

In order to improve the resilience of cities in urban planning, it is necessary to identify the urban recovery indicators that each city should reflect, what plan contents should be specifically set in each divisional plan, I hope that comprehensive research will be carried out to link the subsequent research and city planning with urban resilience in general. 


\section{ACKNOWLEDGEMENT}

This work is financially supported by Korea Ministry of Land, Infrastructure, and Transport (MOLIT) as U-CITY Master and Doctor Course Grant Program.

\section{REFERENCES}

[1] Silva, J., City Resilience Framework, Ove Arup \& Partners International Limited, The Rockefeller Foundation, Arup. 2014.

[2] Kim, H., Kim, T. \& Lee, G., Development of Indicators and Checklist for Urban Disaster Risk Assessment, National Disaster Prevention Education Institute Disaster Prevention Research Institute, 2010.

[3] Seo, J., Nam, K., Min, S., Chung, S. \& Park, A., A Study on the Diagnosis and Utilization of Local Resilience for Sustainable Development, Korea Research Institute for Human Settlements, 2014.

[4] Folke, C., Resilience: the emergence of a perspective for social-ecological system analyses. Global Environmental Change, 16(3), pp. 253-267, 2006.

[5] Godschalk, D.R., Urban Hazard Mitigation: Creating Resilient Cities, Urban Hazard Review, 4(3), pp. 136-143, 2002.

[6] Sophie, B. \& Cassidy, J., Making Cities Resilient Report, UNISDR, 2012.

[7] Yong-Hong, C. (city mayor), 2030 Daejeon Comprehensive Plan, Daejeon City, 2013.

[8] Tae-Young, L. (city mayor), 2030 Suwon Comprehensive Plan, Suwon City, 2014.

[9] Jung-Bok Y. (city mayor), 2030 Incheon Comprehensive Plan, Incheon City, 2015.

[10] Ki-Hyun, K. (city mayor), 2030 Ulsan Comprehensive Plan, Ulsan City, 2016.

[11] Brody, S.D., Examining the role of resource-based industries in ecosystem approaches to management: an evaluation of comprehensive plans in Florida., Soc Nat Resource, 16, pp. 625-641, 2003. 